Papers and Proceedings of the Royal Society of Tasmania, Volume 115, 198]

(ms. received 8.10 .1980$)$

GORDON SUBGROUP (ORDOVICIAN) CARBONATES AT PRECIPITOUS BLUFF AND POINT CECIL, SOUTHERN TASMANIA, AUSTRALIA

Clive Burrett, John Laurie and Bryan Stait

University of Tasmania

(with three text figures)

https://doi.org/l .26749/rstpp.115.93

ABSTRACT

BURRETT, Clive, LAURIE, John and STAIT, Bryan, 1981 (30 ix): Gordon Subgroup

(Ordovician) carbonates at Precipitous Bluff and Point Cecil, southern Tasmania,

Australia. Pap. Proc. R. Soc. Tasm., 115, 93-99 (with three figures). ISSN 0080-

4703. University of Tasmania, Hobart, Tasmania, Australia.

The paldeogeographically and biostratigraphically important ordovician carbonate sequence at Precipitous Bluff is at least $360 \mathrm{~m}$ thick. The lowest $130 \mathrm{~m}$, the New River Beds, consist of bryozoan algal biospararenites of Chazyan to Blackriveran age. These beds were probably deposited in a high energy subtidal environment with minor periods of intertidal deposition. The upper $50 \mathrm{~m}$ of this lowest unit contains abundant Calathium, bryozoans and corals. The succeeding $230 \mathrm{~m}$ of biosparites, biomicrites, argillaceous carbonates and siltstones, the Precipitous Bluff Beds, are dominated by trilobites, brachiopods and bryozoans, range in age from Trentonian to Cincinnatian and were probably deposited in deeper water than the New River Beds.

The Prion Beach Beds at Point Cecil, five km south of Precipitous Bluff, are argillaceous micrites containing a trilobite/brachiopod fauna and include strata of Blackriveran and Trentonian age and are thus biostratigraphically correlated with the upper part of the New River Beds and at least part of the Precipitous Bluff Beds.

Vertical carbonates along New River Lagoon and sheared carbonates at Point Cecil suggest structural complications perhaps associated with a continuation of a large, possibly transcurrent fault, trending north along New River.

\title{
INTRODUCTION
}

This paper records the results of a reconnaissance geological survey of two palaeogeographically important areas of Ordovician carbonates. It will also form the basis for subsequent detailed biostratigraphic studies. Little geological work has been undertaken in this area mainly because of its isolation. Extremely thick vegetation makes geological work very difficult especially away from the cut tracks and no regional structural map can be produced at present.

Johnston (1888) showed 'Silurian' limestone along New River on his map and recorded a coral ('Strombodes') in limestone further north in the Cracroft River (State grid ref. Huon DN 6505). The next published work on the Ordovician limestone at Precipitous Bluff was that of Hughes (1957) who reported the chemical analysis of one sample and commented on its remarkable purity. No further work was carried out until 1979 when a party of the Australian and New Zealand School Exploration Society (ANZSES) led by Mr. Sean Kennedy collected small specimens at $10 \mathrm{~m}$ stratigraphic intervals (Banks in Hawkins 1980).

The argillaceous limestones east of Prion Beach along the western margin of Point Cecil were briefly investigated by Twelvetrees (1915), Blake (in Hughes, 1957), Banks (1962) and the ANZSES party (Kennedy in Hawkins, 1980).

The present study results from two trips to the Precipitous Bluff section (figs 1 and 2) and two trips to the Point Cecil sequence. Access to the general area is difficult but was facilitated by the use of a float plane landing in New River Lagoon and a helicopter landing (or hovering) near the Point Cecil locality allowing the removal of large specimens which could not otherwise be collected in any useful number. 

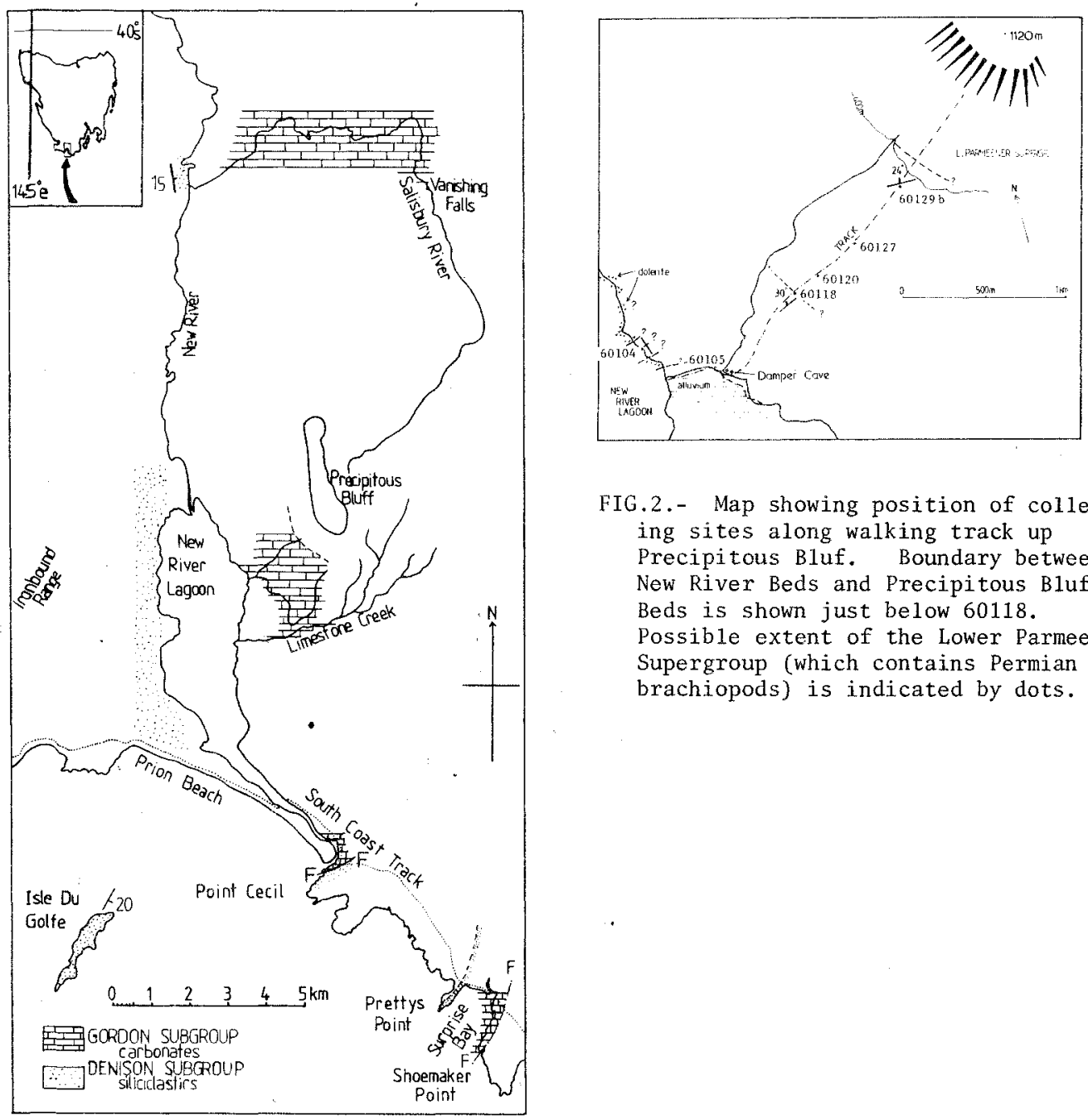

FIG.2.- Map showing position of collecting sites along walking track up Precipitous Bluf. Boundary between New River Beds and Precipitous Bluff Beds is shown just below 60118 .

Possible extent of the Lower Parmeener Supergroup (which contains Permian brachiopods) is indicated by dots.

FIG. 1- Locality map showing part of Southern Tasmania. Extension of Denison Subgroup to north of Salisbury River and Isle du Golfe confirmed by helicopter reconnaissance in 1977 and 1979. F-F = Fault

\section{PRECIPITOUS BLUFF}

The southwestern flanks of Precipitous Bluf are covered by forest that ranges from fairly open to impenetrable. The section was measured along a narrow bushwalking track running up a ridge (State grid ref. Huon, DM664849-DM674861). The thick bush prevents tracing the rock types laterally. Outcrop is very poor from New River Lagoon to the base of a cliff above Damper Cave at grid ref. DM663852. Dolerite, of probable Jurassic age 
Clive Burrett, John Laurie and Bryan Stait

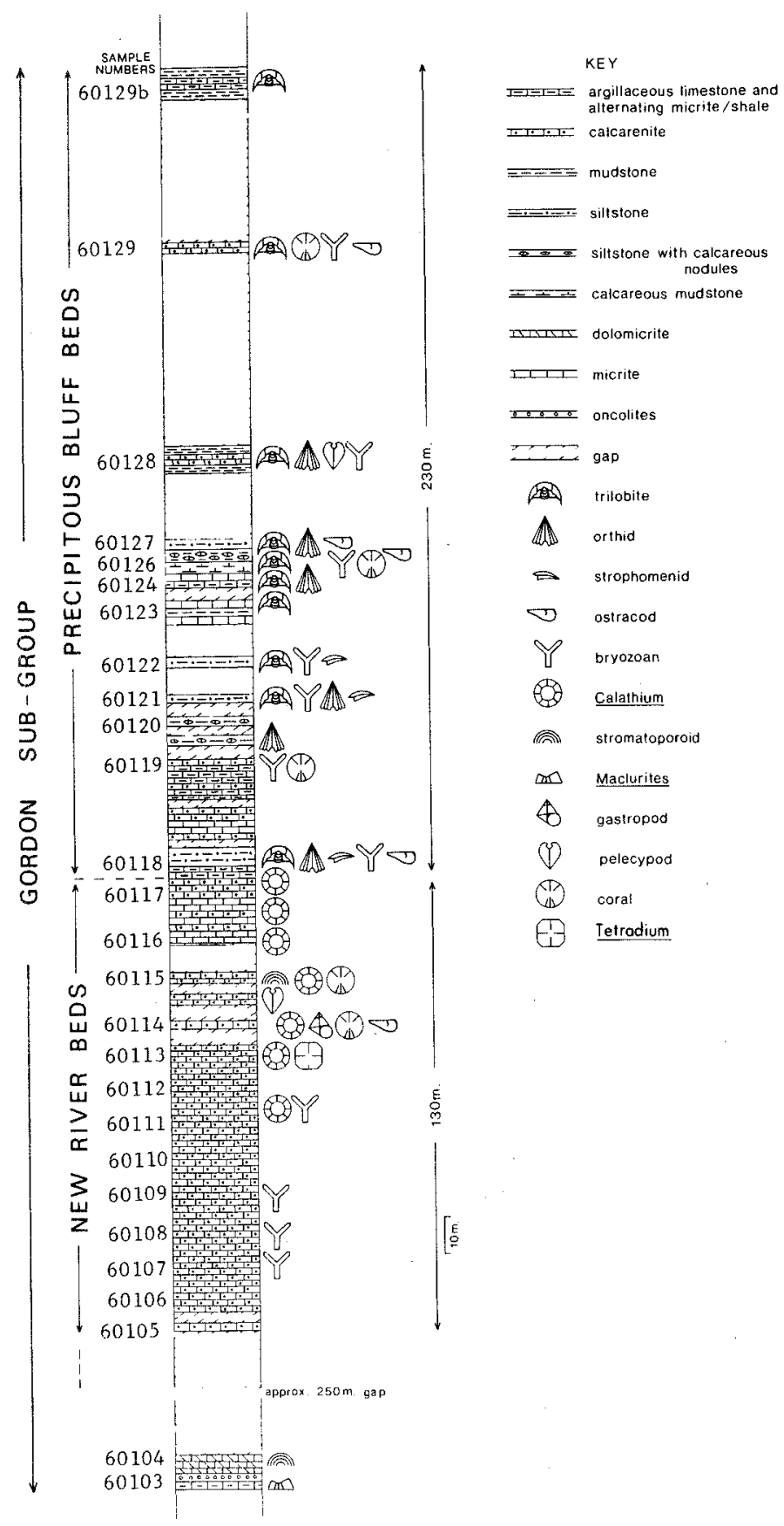

FIG.3.- Stratigraphic column of the Gordon Subgroup at Precipitous Bluff. The thickness of the stratigraphic gap (if any) between samples 60106 and 60105 is not known but could be as much as $250 \mathrm{~m}$. Sample 60114 is dolointrasparite from an outcrop of vertically dipping carbonate. Sample 60115 is from the entrance (lower southern side) of Damper Cave. Sample numbers are catalogue numbers of the University of Tasmania, Geology Department rock collection. 
outcrops along the eastern shore of New River Lagoon from the camp site at grid. ref. DM658851 to near the mouth of New River at DM648868. However one sma11 outcrop of vertically-dipping limestone is present along the shore at grid. ref. DM655854.

The basal $130 \mathrm{~m}$ of the main sequence has excellent (about $80 \%$ outcrop) whereas the upper $230 \mathrm{~m}$ of the sequence contains many large stratigraphic gaps (see fig. 3). As only one na rrow section was measured the sequence is not divided into formations, but rather, beds (Hedberg, 1976) are established awaiting a more complete survey of the regional geology.

Strati graphy

Siliciclastics of the Denison Subgroup (?Late Cambrian-?Mesial Ordovician) outcrop on the western shore of New River Lagoon and along the Ironbound Range (Twelvetrees 1915) but we re not investigated in this study.

Presumably the lowest $12 \mathrm{~m}$ of the carbonate sequence are vertically dipping and consist of a smal1 (20 m $\times 12 \mathrm{~m}$ ) outcrop on the eastern shore of New River Lagoon at grid ref. DM655854 (fig. 2). Impenetrable bush prevents tracing of this outcrop further east and no indication of facing was found. Rock types include dolointramicrudites and dolointrasparites. Five oncolites were found in one $20 \mathrm{~mm}$ thick bed (fig. 3). One stromatoporoid was found in the western part of the outcrop associated with several specimens of Maclurites sp. and other gastropods. Because of their very limited outcrop these intraclastic limestones have not been named. The restricted fauna, the abundant dolomite and the presence of oncolites suggests, by analogy with well-studied sequences elsewhere in the Gordon Subgroup, a peritidal (most likely low intertidal) depositional environment.

No conodonts were found in these beds. E1sewhere in the Gordon Subgroup Maciurites is found only in carbonates of Chazyan age (Banks and Johnson 1957; Banks and Burrett $1980)$.

New River Beds (Gordon Sub-group)

The Macturites-containing carbonates mentioned above are probably separated from the basal units of the main carbonate sequence by a stratigraphic gap. The New River Beds (new name) are a sequence $130 \mathrm{~m}$ thick off cliff-forming, massively-bedded biocalcarenites and biomicrites outcropping on the lower western flanks of Precipitous Bluff between grid refs. DM661852 and DM665864. They dip generally towards the north, east and northeast at angles ranging from $0^{\circ}$ to $32^{\circ}$

The New River Beds are conformably overlain by the Precipitous Bluff Beds. Bedding averages $0.6 \mathrm{~m}$ in thickness, but many beds are lenticular. The New River Beds are mainly biospararenites, intraspararenites, biointraspararenites and biomicrites. Only one bed contains appreciable amounts ( $5 \%$ ) of dolomite (sample UTGD 60113) though several horizons probably contain dedolomites.

Fauna and Flora - Fossils are difficult to see in the field due to recrystallization of the limestone, calcite veining and a covering of moss and lichen. However a major and obvious framework component (especially between samples UTGD 60111 and 60117) is the calcareous alga cf. Catathium which occurs as double-walled, cylindrical or conical structures averaging $35 \mathrm{~mm}$ in diameter. Corals including Tetradium and Pyenolithus (K. Kenna pers. comm.) are present in samples UTGD 60113 and 60114 respectively. In this section, bryozoa, echinodermata and various calcareous algae constitute, in varying proportions, the major bioclasts. Corals and ostracodes are significant, though minor constituents.

The biota is generally stenobiontic and in conjunction with the carbonate types suggests a generally subtidal, high energy environment. Tetradizm and the dolomicrite of samples UTGD 60113 may represent intertidal conditions.

The basal $90 \mathrm{~m}$ of the New River Beds contain rare specimens of Phragmodus flexuosus Moskalenko, Bezodelza copenhagenensis (Ethington and Schumacher), Drepanoistodus 
Clive Burrett, John Laurie and Bryan Stait

suberectus (Branson and Meh1), BeZodina monitorensis (Ethington and Schumacher) and Panderodas racizis (Branson and Mehl). This fauna suggests a Chazyan age. Sample UTGD 60116 contains Tumunoghathus careyi which suggests a Blackriveran age (Burrett 1979)

Precipitous Bluff Bed's (Gordon Sub-group)

The ?recipitous Bluff Beds (new name) are a sequence $230 \mathrm{~m}$ thick of thinly-bedded siliceous siltstones, calcareous shales, biomicrites and biospararenites outcropping along a ridge from grid rofs [M665854 to DM673859. These beds conformably overlie the New River Beds and are overlain unconformably by fossiliferous marine rocks belonging to the Lower Parmeener Supergroup of Late Carboniferous-Permian age.

The collact between the New River Beds and the overlying Precipitous Bluff Beds is gradational but within a 3 m thickness decalcified siltstone replaces biomicrite and thereafter siltstones and shales are common in alternations with biocalcarenites and biomicrites. Bedding thickness is variable $(0.5 \mathrm{~m}-50 \mathrm{~mm})$ but beds are rarely thick.

Fauna - The $4 \mathrm{~m}$ thick basal siltstone is decalcified, buff-coloured and lithologically very similar to the Lords Siltstone Member in the Florentine Valley (Corbett and Banks 1974).

The brachiopod fauna includes most of the species found in the Lords Siltstone including Strophomena sp. nov., Sowerbyites vesciseptus Percival, but also contains Ptychopleurella sp. nov., PLeptellina sp., Clitambonites (Clitambonites) sp., Skenidioides sp. nov., ?Halzina, Souerbuezla cf. anticipata Percival and a new genus of resupinate leptellinid. Sowerbytes vesciseptus and Sowerbyezza anticipata occur in Fauna III (Eastonian) of New South Wales (Perciva1, pers. comm).

Trilobites from this level include Remopleumides sp., Pliomerina sp. and Amphilichas sp. (Banks, pers. comm.). A drepanellid ostracode (new genus A) is also common.

Conodonts are present in sample UTGD 60118 and include Phragmodus undatus (Branson and Meh1j and Plectodtho aculeata (Stauffer) and suggest an Early Trentonian (Rock1andian) age.

Sample 60128 contains Aphelognathus sp. and sample 60129 contains Oulodus robustus (Branson, Meh1 \& Branson), Pseudobezodina sp., and ApheZognathus shoshonensis Sweet artd suggests a Late Edenicm-Mesial Maysvillian age.

\section{POINT CECIL AREA}

Prion Beach Beds (Gordon Subgroup) and Denison Subgroup at Point Cecil.

The argillaceous carbonates at Point Cecil to the east of Prion Beach (see fig. 2) were first mentioned by Twelvetrees (1915). Blake (in Hughes, 1957), described them as dark limestones alternating with slates. Banks (1962, p.170) recorded Ampyx and a cryptolithid close to Eirelithus from this Locality and suggested a Mesial Ordovician age. The argillaceous limestones are thinly-bedded, steeply-dipping (between $75^{\circ}-90^{\circ}$ ) and are faulted against the underlying Denison Subgroup quartz arenites. The basal limestone beds contain abundant detrital quartz. Further to the east (at DM677774 on South East Cape, 1:100 000 Sheet No. 8210) the Denison Subgroup quartz arenites are shallowly dipping (between $25^{\circ}-30^{\circ}$ ) to the west and are, from the evidence of trough cross-bedding, right way-up. The quartz arerites are approximately $150 \mathrm{~m}$ thick, contain minor oligomict microconglomerates and overiie a conglomerate sequence of unknown thickness.

The argillaceous linestone outcropping along the western side of Point Cecil from grid ref. DM678775 to grid ref. CM681782 is herein named the Prion Beach Beds. Shearing and folding preclude any estimate of their true thickness but it is unlikely to exceed $200 \mathrm{~m}$. Several sma11 north-east trending transcurrent faults are present, extending for several metres approximately parallel to strike $\left(N 60^{\circ} \mathrm{E}\right)$. The drag dip on these transcurrent faults indicates sinistral movement. About $150 \mathrm{~m}$ north-northeast of this shear 
zone the limestones dip at $5^{\circ}$ to the northwest.

Fauna - The Prion Beach Beds contain an abundant fauna of fragmentary trilobites. More complete trinucleid trilobites are found $20 \mathrm{~m}$ north of the base of these beds and are associated with a brachiopod fauna that includes Sowerbyelza cf. Lepta Percival. A drepanellid ostracode (new genus A) is also found at this level. Conodonts are generally poorly preserved in these beds but include Phragmodus undetus in a sample not stratigraphically precisely located and Phragmodus inflexus Stauffer in a sample $10 \mathrm{~m}$ above the base of the beds. The former indicates a Trentonian or younger age and the latter indicates a Blackriveran age.

\section{CONCLUSIONS}

The carbonate sequence at Precipitous Bluff is divisible into 2 main lithostratigraphic units. The lower biospararenitic New River Beds were probably deposited in a subtidal environment. These beds were deposited during the Chazyan and Blackriveran at the same time as peritidal carbonates were deposited in many other parts of the state (e.g. Ida Bay, Florentine Valley, Vale of Belvoir, Everlasting Hills: Burrett 1979; Calver 1977; Weldon 1974). The higher parts of the New River Beds were also deposited at the same time as the deeper-water Prion Beach Beds. The succeeditag Precipitous Bluff Beds suggest a deeper water environment and were deposited at the same time as very shallow subtidal-peritidal carbonates were deposited at Ida Bay and in the Florentine Valley and at the same time as part of the even deeper Prion Beach Beds.

The brachiopods from the base of the Precipitous Bluff Beds include elements found in the Florentine Valley and at Mole Creek but also include species only previously known from New South Wales.

The conodont fauna also allows correlation with deeper-water sequences outside Tasmania. Several important conodonts such as Pseudobelodiria sp., Aphelognathus shoshonensis and Phragmodus inflexus, that facilitate precise intercontinental correlation, are found in this area but have not been found elsewhere in Tasmania. Further work in this area will undoubtedly reveal an Ordovician sequence of great jimportance in intercontinental correlations.

The vertically dipping carbonates along New River Lagoon and the sheared and possibly overturned sequence near Point Cecil suggests structural complications perhaps associated with the continuation of the transcurrent Lake Edgar Fault along New River as suggested by Corbett (1970).

\section{ACKNOWLEDGEMENTS}

This study was supported by the Australian Research Grants Committee (grant to M.R. Banks and C.F.B.) and the Gloyne Fund of the Geological Society of London to C.F. Burrett. Additional helicopter support was provided by the koyal Australian Air Force. We are indebted to Wing Commander Murray, and the helicopter crew G. Forbes, A. Stone and M. Ryan. The help of R. Andrewartha of Waterbird Aviation is gratefully acknowledged. Expert help in the field was provided by R. Berry, A. Bush, S. Harley and D. Seymour and M.R. Banks, A. Goede, K. Kenna, S. Kennedy and C. Sharples provided useful information.

\section{REFERENCES}

Banks, M.R., 1962: The Ordovician System. In Spry, A. and Manks, M.R. (Eds): THE GEOLOGY OF TASMANIA. J. geot. Soc. Aust. 9(2): 147-176.

Banks, M.R. and Burrett, C.F., 1980: A preliminary Ordoviciar 1.dotratigraphy of Tasmania. J. geot. Soc. Aust. 26: 363-376.

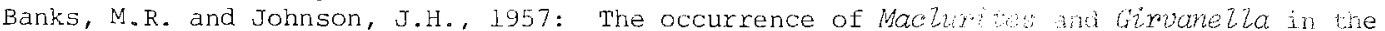
Gordon Limestone (Ordovician) of Tasmania. J. Paleont. 3?:632-640. 
Clive Burrett, John Laurie and Bryan Stait

Burrett, C.F., 1979: Tasmanognathus: a new Ordovician conodontophorid genus from Tasmania. Geologica et Falaeontologica 13: 31-38.

Calver, C.R., 1977: Palaeoecology of the Lower Limestone Member, Benjamin Limestone, Florentine valley. University of Tasmania, unpub. thesis.

Corbett, K.D., 1970: Sedimentology of an Upper Cambrian Flysch-Paralic Sequence (Denison Group) on the Denison Range, Tasmania. University of Tasmania, unpub. thesis.

and Banks, M.R., 3.974: Ordovician stratigraphy of the Florentine synclinorium, southwest Tasmania. Pap. Proc. R. Soc. Tasm, 107: 207-238.

Hawkins, T.W.J. (Ed.), J980: EXPEDITION NEW RIVER - REPORT. Australian and New Zealand Schools Exploring Society. La Trobe University Press, Bundoora, 101pp.

Hedberg, H.D. (Ed.), 1976: INTERNATIONAL STRATIGRAPHIC GUIDE. Wiley-Interscience, New York, 200pp.

Hughes, T.D., 1957: Limestones in Tasmania. Tasmanian Dept. Mines Mineral Resources 10: $1-291$.

Johnston, R.M., 1888: SYSTEMATIC ACCOUNT OF THE GEOLOGY OF TASMANIA. Walch, Hobart, $408 \mathrm{pp}$.

Twelvetrees, W.H., 1915: Reconnaissance of country between Recherche Bay and New River, southern Tasmania. BuZZ. geol. Sum. Tasm., 24: 1-38.

Weldon, B.D., 1974: Carbonate lithofacies and depositional environments of the ordovician Gordon Limestone Subgroup, Florentine Valley. University of Tasmania, unpub. thesis. 